\title{
Corporate Governance and Efficiency in the Electricity Sector using Data Envelopment Analysis: a study in the Brazilian stock market
}

\author{
Fernanda Maciel Peixoto ${ }^{1}$ \\ Roberto do Nascimento Ferreira ${ }^{2}$ \\ Ana Lúcia Miranda Lopes ${ }^{3}$ \\ André Francisco Alcântara Fagundes ${ }^{4}$
}

\section{Abstract}

Different Corporate Governance mechanisms have been suggested to minimize agency problems between managers and shareholders, and between controlling and minority shareholders. The aim of this study is to analyze whether the corporate governance mechanisms result in greater efficiency for Brazilian stock companies in the electricity sector, in 2007-2009. The hypothesis to be verified is that the lower the voting concentration and the dependence of the council, and the greater the cash flow concentration, the greater the performance of the company will be. The analyzed sample involved thirty-three companies, fourteen being classified into one of the levels of CG (Level 1, Level 2 or New Market) and the remainder being members of the traditional market. To measure the efficiency of the companies, the non-parametric DEA (Data Envelopment Analysis) method was used, and to relate the efficiency with the governance variables, we adopted regression analysis of panel data. The results demonstrated that the use of CG mechanisms positively influences business efficiency, but not in the expected magnitude. It was found that the cash flow concentration is positively related to the efficiency of firms, supporting the governance literature. For future work, the use of other input and output variables is suggested.

1 Professora da Universidade Federal de Uberlândia - UFU. End.: Av. João Naves de Ávila, 2121, Santa Mônica, Uberlândia - MG. CEP: 38400-902 - Brasil. E-mail: fmacielpeixoto@gmail.com.

2 Professor da Universidade Federal de São João del-Rei. End.: Campus Tancredo de Almeida Neves - CTAN, Departamento de Ciências Administrativas e Contábeis, Av. Visconde do Rio Preto, s/nº, Sala 2.10, Colônia do Bengo, São João del-Rei - MG. CEP: 36301-360 - Brasil. E-mail: roberto@ufsj.edu.br.

3 Professora da Pós-Graduação e Pesquisas em Administração - CEPEAD da Universidade Federal de Minas Gerais - UFMG. End.: Av. Antonio Carlos, 6627, FACE/UFMG, sala 4042, Pampulha, Belo Horizonte - MG. CEP: 31270-901 - Brasil. E-mail: analopes. ufmg@gmail.com.

4 Professor da Universidade Federal de Uberlândia - UFU. End.: Av. João Naves de Ávila, 2121, Santa Mônica, Uberlandia - MG. CEP: 38400-902 - Brasil. E-mail: andrefagundes@fagen.ufu.br.

Artigo recebido em: 18/03/2011. Aceito em: 20/08/2011. Membro do Corpo Editorial Científico responsável pelo processo editorial: Thomas G. Brashear.

(c) (i) (9) Esta obra está sob uma Licença Creative Commons Atribuição-Uso. 
Key words: Corporate Governance. Efficiency and Data Envelopment Analysis.

\section{Introduction}

Assuming that a particular company is willing to incorporate and/or improve corporate governance practices, while keeping other corporate aspects unchanged. Will this decision affect its efficiency? How? This paper aims to answer this question by investigating a possible link between good corporate governance and business efficiency. In this sense, the objective of this study is to evaluate whether the mechanisms of corporate governance of publicly traded companies in the electricity sector traded at Bovespa (São Paulo Stock Exchange) may positively influence their efficiency (or operating performance) in the period between 2007 and 2009.

Therefore, the main hypothesis of this study is: there is a positive relationship between the adoption of good corporate governance and business efficiency. It is assumed that the lower the voting concentration and the dependence of the council, and the greater the cash flow concentration, the greater the performance of the company will be. To test this hypothesis, this study was divided into two main steps: (a) use of the DEA (Data Envelopment Analysis) method to obtain a score of corporate efficiency; and (b) estimation of regression models to verify the existence of a relationship between the score obtained in "a" and corporate governance variables.

The variables used in the first stage searched to describe the operational nature of the companies under study, involving the process of converting inputs (expenditure, debt and patrimony) in business products (revenue, Tobin's Q and return on assets). The variables on governance of the second stage involved aspects linked to the property of the controlling shareholder and to the level of independence of the board, as suggested by Silveira (2004) and Carvalhal-da-Silva and Leal (2005).

As a result, we found significant associations between the variable DSFC (rights over the cash flow) and the efficiency score, indicating that a higher cash flow concentration leads to greater efficiency in the organizations analyzed. These results were consistent with recent research on the topic (CARVALHAL-DA-SILVA; LEAL, 2005; CLAESSENS et al., 2002; DOIDGE et al., 2005). 
The literature on the subject (CARVALHAL-DA-SILVA; LEAL, 2005; CORREIA, 2008; SILVEIRA, 2004) usually relates corporate governance to performance/business value without going through the efficiency analysis and without taking the operational nature of the companies under study directly into consideration. The efficiency indicators, based on the economic theory of production, provide an alternative for measuring business performance in countries with an incipient stock market and low legal protection for investors (LOVELL, 1993; ZHEKA, 2005). This study seeks to fulfill this gap in the literature on the subject and differs from other studies for relating Governance to Business Efficiency.

The paper is structured as follows: section 2 provides literature revision on corporate governance and on studies that address governance and business efficiency. Section 3 presents the research methodology of the study. Section 4 describes the results obtained. Section 5 concludes the text.

\section{Theoretical Framework}

\subsection{Corporate Governance}

When considering corporate governance worldwide, we can say that the precursors of the concept were Berle and Means (1932), when they investigated the modalities of control of the 200 largest U.S. companies in the early 1930s. Next, we highlight the studies of Coase (1937) with the Theory of Transaction Costs and Williamson (1985) with studies on ex-post costs, limited rationality, and opportunism of agents and assets specificity. In 1976, Jensen and Meckling publish their work "Theory of the firm: managerial behavior, agency costs and capital structure", discussing the agency, property rights and finance theories in order to establish the theoretical basis for the organizations ownership structure. Shleifer and Vishny (1997) discuss the legal protection of the investor and the ownership concentration in the worldwide governance systems. Then, they present one of the most commonly used concepts on the subject from the perspective of agency theory: "corporate governance deals with the ways in which investors ensure your return on investment" (SHLEIFER; VISHNY, 1997, p. 737). 
In the 1990s, in response to corporate and financial scandals occurred in England, the Cadbury Report was prepared (1992), in order to elaborate effective Boards of Directors. Another prominent regulatory response was the Sarbanes-Oxley Act (SOX), enacted in July 2002 by the U.S. congress, which purpose was to restore the level of confidence in the information generated by the companies and provide support for the efficiency and development of financial markets.

Nowadays, Corporate Governance has become notorious by studies that associate it to an improvement in operating and financial performance and consequent recognition by the capital market. There are extensive studies on the relationship between governance and performance, such as: Aguiar, Corrar and Baristella (2004); Carvalhal-da-Silva and Leal (2005); Carvalho (2003); Correia (2008); Lameira, Ness Jr. and Da Motta (2005); Rabelo, Rogers and Ribeiro (2007); Rogers (2006); and Silveira (2004).

Such studies search to analyze the relationship between Corporate Governance (CG) and different performance indicators, such as: profitability, liquidity, risk, capital cost and volatility. It is aimed to identify whether publicly traded companies in Bovespa, which adhered to the principles of CG and/or companies who have reached higher levels of CG, can achieve better performance than companies belonging to the traditional market.

The discussion about corporate governance assumes that the governance mechanisms influence the performance of companies. However, in spite of the extensive range of studies, there is still no consolidated theoretical framework or conclusive empirical evidence about how (and if) governance mechanisms influence corporate performance and about how these mechanisms are related to each other, whether as a complement or substitute (ROGERS, 2006).

Several authors have addressed the advantages obtained by companies that adopt good corporate governance practices. According to Andrade and Rossetti (2006, p. 235), Corporate Governance brings a healthy business mood that generates many benefits, among which: (1) it avoids: abuse of power and extortionate agency costs, strategic errors, mismanagement and corporate fraud; and (2) it promotes: confidence in the business world, increasing canalization of resources to the capital markets, and wide involvement of society in the process of economic expansion.

For Rogers (2006, p. 18), establishing standards, behavior models and rules to ensure that capital providers (creditors and minority shareholders) have 
their return, leads to a greater demand by investors for company shares. According to the author, this translates as follows: "for the company, it means raising funds at lower costs, with the probability of higher returns on investments; and for shareholders, it means increased dividends."

In Brazil, the model of Corporate Governance has become better known in 2001, after the creation of Bovespa's CGI (Corporate Governance Index). The Brazilian model still requires improvements for the following reasons: inexpressive capital market; shareholding concentration; property-management overlapping, agency conflicts between majority and minority shareholders; weak protection for minority shareholders; low effectiveness of the Board of Directors; model focused on the interests of owners, among other factors. However, there are signs of progress, mainly due to the recent process of privatization, mergers, entry of foreign investments in the country, corporate restructuring in publicly traded companies, changes in their ownership and management structures, increasing professionalization of the Councils, increase of initial public offerings (IPOs) and raising awareness of the business class (ANDRADE; ROSSETTI, 2006).

Given this context, according to Silveira (2004) and Carvalhal-da-Silva and Leal (2005) there are some variables that assume real importance in the analysis of corporate governance in the Brazilian stock market, which are: the right of control (voting rights) of the controlling shareholder, represented by the percentage of shares held by them; the rights on the cash flow(ownership rights of the controller), represented by the percentage of his stake in the company and the level of dependency of the board, aspects that are addressed in empirical part of this study.

Bovespa has created differentiated levels of corporate governance, which are divided into Level 1, Level 2 and Novo Mercado ("New Market"), for the trading of shares issued by companies that voluntarily commit themselves to the adoption of additional corporate governance practices in relation to what is required by law. The IGC index developed by Bovespa is made only by companies that have adopted the practices of the differentiated levels of governance.

The main innovation of Novo Mercado for the traditional market is the requirement that the company's social capital must be solely constituted by ordinary shares. In Level 1 the companies are committed mainly to improvements in providing information to the market and with share dilution. In Level 2 the companies are committed with the rules applicable to Level 1 and, additionally, 
a broader set of governance practices relating to corporate rights of minority shareholders ${ }^{5}$.

\subsection{Studies on Corporate Governance and Business Efficiency}

With respect to studies relating corporate governance to business efficiency, there are some interesting lines of investigation. Hardwick, Adams and Zou (2003) investigated the association between the role of the councils and the cost efficiency of life insurers in the UK between 1994 and 1999.The results show that the proportion of outside directors on the board and the separation of functions between $\mathrm{CEO}$ and Chairman proved to reduce the cost efficiency of life insurers, contesting the traditional literature on the role of boards of management (HERMALIN; WEISBACH, 2003; JENSEN, 1993).

In another line of analysis, Lehmann, Warning and Weigand (2004) search to identify the relationship between profitability and organizational efficiency regarding to the structures of corporate governance. Using data from $361 \mathrm{Ger}-$ man companies, they test the hypothesis that companies with effective governance structures have higher profitability. The results showed that the efficiency scores of governance structures contribute significantly to explain differences in profitability between companies, confirming their hypothesis.

Under a similar point of view, Zheka (2005) analyzed governance, property structure and corporate efficiency in Ukraine between 2000 and 2001. He found that the identity of the controllers and the concentration of property rights partly explain the efficiency of firms in his sample. He also found that good corporate governance practices have a positive relationship with the efficiency of domestic firms, while foreign-controlled firms demonstrate better CG practices.

Destefanis and Sena (2007) aimed to examine the relationship between the corporate governance system and technical efficiency in Italian industry. Two dimensions of governance proved to have a positive impact on efficiency: the percentage of shares held by the company's largest shareholder and the fact that a company belongs to a group with a pyramidal structure.

From a different point of view, Huang, Lai and Hsiao (2007) analyzed the property structure, manager compensation and performance of life insurers in

5 For details about the legal requirements to participate in each of Bovespa's IGC listing segmentsseewww.bovespa.com.br. 
Taiwan. The results showed that the higher the percentage of shares held by executives the more likely to improve the performance of insurers.

To analyze the relationship between performance and composition of the board of directors of a group of 14 Canadian SOEs between 1976 and 2001 was the goal of the Bozec and Dias (2007) research. The results showed a positive relationship between board independence and performance, when the market is deregulated; and a negative relationship between proportion of public servants on the board and performance, when SOEs are subject to market rules.

The work of Feroz, Raab and Goel (2008) attempted to calculate the relative performance of the governance structure of a number of pharmaceutical companies. The analysis indicated that the positions of efficiency are related to the strategic choices made by upper management. According to the authors, their approach may be appropriate to evaluate strategic managers (CEOs, general managers and presidents) through the board, by relating multiple performance indexes towards an overall goal.

In another line of investigation, Macedo and Corrar (2009) studied accounting and financial companies with good CG practices and others without good CG practices, in the electric power sector in Brazil, from 2005 to 2007. The sample included 26 electric power sector companies, 8 with good CG practices and 18 without good CG practices. The authors concluded that, in the year of 2005 and considering the average performance in the entire period, companies with good CG practices demonstrate statistically higher accounting and financial performance. However, for the years 2006 and 2007, the performance of both groups (with and without CG) is statistically equal to the $5 \%$ level of significance.

\section{Methodology}

The empirical analysis was based on data from Brazilian electricity companies with stocks traded at Bovespa, from 2007 to 2009. The choice of this sector was motivated by the representativeness in national economy, and its importance for the country's development. As pointed out by Alves, Ribeiro and Mantese (2007), due to its utility and relevance in public infrastructure, the electricity sector is crucial to national development. Electricity is the basic product for both the general population (residential consumption) and for companies from all sectors (commercial or industrial use). Furthermore, it should be also 
noted that the changes in the regulatory structure of the sector in recent years and significant amounts of private capital that it has recently attracted justify the need for an analysis of the current levels of transparency and governance and its relationship with business efficiency.

Data on inputs and outputs were collected from the Economática database and data relating to corporate governance practices were extracted from the Securities and Exchange Commission (CVM - Comissão de Valores Mobiliários) website. The description of the variables used in this study is in the Appendix, Table A.

This study involved two main steps ${ }^{6}$ :

a) Application of the DEA (Data Envelopment Analysis) model to reach the firms efficiency score. At this stage, the focus is an analysis of the conversion of financial inputs (expenditure, debt and equity) in financial products as well (revenue, market value and ROA), in order to obtain an efficiency indicator.

b) Use of Regression Analysis of Panel Data to check a possible relationship between the obtained score in the first stage and corporate governance variables.

Data Envelopment Analysis - $\mathrm{DEA}^{7}$ is a set of non-parametric models that measures the relative efficiency of decision making units (DMU's) after explicit consideration of the use of multiple inputs to produce multiple outputs. It is a methodology that causes the decision to be driven by a single indicator constructed from several different approaches to performance (COOK; ZHU, 2003; COOPER; SEIFORD; TONE, 2007).

There are two basic DEA models which are commonly used in applications. The first is the CRS (Constant Returns to Scale), used when products and inputs increase or decrease following the same factor $k$. The second is the VRS (Variable Returns to Scale), used when the increase/decrease of output/input is not proportional in the units of analysis (COOK; ZHU, 2003).

There are two possibilities for model orientation: input orientated, where the score is obtained by the maximum reduction of inputs for the same output

6 To view the main steps of this study, see the Appendix, Fig. A.

7 Based on the studies of Farrell (1957), Charnes, Cooper and Rhodes (1978) proposed an on parametric approach to efficiency analysis with multiple inputs and multiple outputs, called Data Envelopment Analysis (DEA). (LINS; MEZA, 2000; VILELA; MERLO; NAGANO, 2007). 
production; and output oriented that seeks to maximize the outputs, given the fixed amount of inputs (COOPER; SEIFORD; TONE, 2007).

The input variables used in this study are: Operating Expenses, Total Liabilities and Equity ${ }^{8}$, while the output variables are: Net Operating Income, Tobin's Q and Return on Assets (ROA).

In the first stage, the input-oriented DEA-VRS (BANKER; CHARNES; COOPER, 1984) was applied, as proposed by Zheka (2005). The linear programming problem solved in this study is represented in FIG. 1.

$$
\operatorname{Min} \theta-\varepsilon\left(\sum_{i=1}^{m} \mathrm{~s}_{\mathrm{i}}^{-}+\sum_{r=1}^{s} \mathrm{~s}_{\mathrm{r}}^{+}\right)
$$

subject to

$$
\begin{aligned}
& \sum_{j=1}^{n} \lambda_{j} \mathrm{x}_{\mathrm{ij}}+\mathrm{s}_{i}^{-}=\theta \mathrm{x}_{i 0}, \quad \mathrm{i}=1,2, \ldots, \mathrm{m} ; \\
& \sum_{j=1}^{n} \lambda_{\mathrm{j}} \mathrm{y}_{\mathrm{rj}}-\mathrm{s}_{r}^{+}=\mathrm{y}_{r 0}, \quad \mathrm{r}=1,2, \ldots, \mathrm{s} ; \\
& \sum_{j=1}^{n} \lambda_{\mathrm{j}}=1
\end{aligned}
$$

Figure 1: DEA-VRS - Input-Oriented Envelopment Model

Source: Cook and Zhu (2003, p. 128)

Where $\theta$ is the input-oriented efficiency score; $\mathrm{x}_{\mathrm{i} 0}$ and $\mathrm{y}_{\mathrm{r} 0}$ are the ith input and $r_{\text {th }}$ output quantities, respectively, from the DMU 0 that is under analysis; $x_{i j}$ and $\mathrm{y}_{\mathrm{rj}}$ are the $\mathrm{i}_{\text {th }}$ input $(\mathrm{i}=1, \ldots \mathrm{m})$ and $\mathrm{r}_{\text {th }}$ output $(\mathrm{r}=1, \ldots, \mathrm{s})$ quantities for DMU $\mathrm{j}(\mathrm{j}=1, \ldots, n)$, respectively; $s_{i}^{-}$and $s_{r}{ }^{+}$are the slacks in inputs and outputs and $\lambda \mathrm{j}$ are the unknown weights. The problem must be solved $\mathrm{N}$ times, once for each company and the obtained value of $0<\theta \leq 1$ is the efficiency score for firm 0 . If $\theta=1$, then the company is on the frontier. If $\theta=1$ and the slacks are zero this firm is considered efficient.

According to Lovell (1993), the DEA model does not require an assumption that data distribution is normal and the DEA score generated may be used in a regression analysis. One of the main advantages of its use is the non-requirement

8 The rationale for selecting these variables (and the others involved in this work) was based on literature on the topic and is presented in Appendix Table A. 
of a functional form. Moreover Lovell (1993) points out that the DEA does not measure the random error term that is common in the regressions, but as the DEA score is often used in a regression in the second stage of the work, it is possible to join both models benefits.

Thus, in the second stage of the study, we used regression analysis of panel data to estimate the relationship between efficiency and corporate governance, using the following logic:

$$
\begin{aligned}
& \mathrm{EF}_{\text {it }}=\mathrm{f} \text { (Governance Variables, Control Variables) } \\
& \mathrm{EF}_{\text {it }}=\mathrm{f} \text { (DCONT; DSFC; DCONT and DSFC Separation; GIC; Adhe- } \\
& \text { sion to NDGC; Size) }
\end{aligned}
$$

Where $\mathrm{EF}_{\text {it }}$ represents the efficiency score of firm $i$, in period $t$, obtained with a DEA-VRS model.

Therefore, to represent the corporate governance mechanisms, the following variables have been used: control rights (DCONT), cash flow ownership (DSFC), separation between DCONT and DSFC and degree of independence of the board (GIC). Moreover, aiming to study other aspects that might also affect business efficiency, a few control variables have been adopted, namely: natural logarithm of total assets as a proxy of company size and adhesion to Bovespa's corporate governance levels (NDGC).

\section{Analysis of the Results}

\subsection{Efficiency DEA Analysis}

Based on information from Brazilian electricity companies (2007, 2008 and 2009), the efficiency scores were calculated. The results are shown in Table 1.

In 2007, fifteen companies had efficiency scores equal to 1 . These are AESElpa, AESTietê, Afluente, CEB, CEEE-GT, Celesc, Cemig, Copel, CPFLEnergia, Elektro, Eletrobrás, Eletropaulo, MPXEnergia, Rede Energia and Terna Participacões. In the group of efficient ones, eight companies have traded their shares on Bovespa's differentiated levels of corporate governance. It is important to notice that the companies Cesp, Emae and Geração Paranapanema showed very low levels of efficiency when compared to the other companies, even though shares from Cesp are listed under corporate governance Level1. 
In 2008 it was observed that CEB, CEEE-GT, MPXEnergia and Terna Participações that were considered efficient in 2007 (scores = 1), did not show the same performance. Interesting to observe that MPX Energia, a company that belongs to the New Market (NM) had its efficiency score decreased substantially from 2007 to $2008^{9}$. In 2008, from the twelve companies considered efficient, six $(50 \%)$ are listed at differentiated levels of corporate governance.

In 2009, the company lenergia, which was not classified as efficient in the two previous years, had level of efficiency equal to1. In this year, as well as in 2008, among the twelve companies considered efficient, six are listed at differentiated levels of corporate governance.

Table 1: Efficiency scores for each year and period average

\begin{tabular}{|l|l|l|l|l|l|}
\hline \multicolumn{1}{|c|}{ COMPANIES } & CG Levels & \multicolumn{1}{|c|}{$\mathbf{2 0 0 7}$} & \multicolumn{1}{|c|}{$\mathbf{2 0 0 8}$} & \multicolumn{1}{|c|}{$\mathbf{2 0 0 9}$} & \multicolumn{1}{c|}{ Average } \\
\hline AESElpa & & 1 & 1 & 1 & 1 \\
\hline AESTietê & & 1 & 1 & 1 & 1 \\
\hline Afluente & & 1 & 1 & 1 & 1 \\
\hline AmplaEner & & 0,578468 & 0,661392 & 0,759043 & 0,666301 \\
\hline CEB & & 1 & 0,861415 & 0,804320 & 0,888578 \\
\hline CEEE-GT & $\mathrm{N} 1$ & 1 & 0,721405 & 0,358893 & 0,693433 \\
\hline Celesc & $\mathrm{N} 2$ & 1 & 1 & 1 & 1 \\
\hline Celpa & & 0,453717 & 0,446834 & 0,440126 & 0,446892 \\
\hline Celpe & & 0,750118 & 0,745382 & 0,873388 & 0,789629 \\
\hline Cemar & & 0,717602 & 0,624820 & 0,576640 & 0,639687 \\
\hline Cemat & & 0,508458 & 0,490747 & 0,516465 & 0,505223 \\
\hline Cemig & $\mathrm{N} 1$ & 1 & 1 & 1 & 1 \\
\hline Cesp & $\mathrm{N} 1$ & 0,196286 & 0,250073 & 0,290546 & 0,245635 \\
\hline Coelba & & 0,864720 & 1 & 0,948481 & 0,937734 \\
\hline Coelce & & 0,873307 & 0,855529 & 0,899541 & 0,876126 \\
\hline Copel & $\mathrm{N} 1$ & 1 & 1 & 1 & 1 \\
\hline Cosern & & 0,755967 & 0,739073 & 0,699669 & 0,731570 \\
\hline
\end{tabular}

Source: Research data

9 We must interpret this result with caution, since that there are missing data for MPX in Economática database, and its operating income from 2007 was not presented at the base. 


\begin{tabular}{|l|l|l|l|l|l|}
\hline \multicolumn{1}{|c|}{ COMPANIES } & \multicolumn{1}{|c|}{ CG Levels } & \multicolumn{1}{|c|}{$\mathbf{2 0 0 7}$} & \multicolumn{1}{|c|}{$\mathbf{2 0 0 8}$} & \multicolumn{1}{|c|}{$\mathbf{2 0 0 9}$} & \multicolumn{1}{c|}{ Average } \\
\hline CPFLEnergia & $\mathrm{NM}$ & 1 & 1 & 1 & 1 \\
\hline Elektro & & 1 & 1 & 1 & 1 \\
\hline Eletrobrás & $\mathrm{N} 1$ & 1 & 1 & 1 & 1 \\
\hline Eletropar & & 0,823465 & 0,834745 & 1 & 0,886070 \\
\hline Eletropaulo & $\mathrm{N} 2$ & 1 & 1 & 1 & 1 \\
\hline Emae & & 0,215243 & 0,542198 & 0,302921 & 0,353454 \\
\hline EnergiasBR & $\mathrm{NM}$ & 0,753685 & 0,681484 & 0,559686 & 0,664952 \\
\hline Equatorial & $\mathrm{NM}$ & 0,545193 & 0,648500 & 0,643282 & 0,612325 \\
\hline GerParanap & & 0,299460 & 0,419972 & 0,516915 & 0,412116 \\
\hline Inergia & & 0,626721 & 0,534610 & 1 & 0,720444 \\
\hline Light & $\mathrm{NM}$ & 0,867449 & 0,908457 & 0,798177 & 0,858028 \\
\hline MPXEnergia & $\mathrm{NM}$ & 1 & 0,047231 & 0,020285 & 0,355839 \\
\hline RedeEnergia & & 1 & 1 & 0,791704 & 0,930568 \\
\hline TernaPart & & 1 & 0,322572 & 0,396260 & 0,572944 \\
\hline Tractebel & $\mathrm{NM}$ & 0,847004 & 0,705001 & 0,534413 & 0,695473 \\
\hline TranPaulist & $\mathrm{N} 1$ & 0,669131 & 0,731961 & 0,592793 & 0,664628 \\
\hline
\end{tabular}

Source: Research data

Companies AESElpa, AESTietê, Afluente, Celesc, Cemig, Copel, CPFLEnergia, Elektro, Eletrobrás and Eletropaulo had maximum performance in the three years analyzed. Companies Coelba and Rede Energia had good performance on average, due to the fact that they have been considered efficient in at least one year during the period analyzed.

It is observed that the average efficiency levels decreased over the years (Table 2). In 2007 the average score of efficiency was 0.79836 , decreasing to 0.73708 in 2009 . For companies listed under corporate governance levels, the decrease was more significant, changing from a mean score of 0.848482 in 2007 to 0.763865 in 2008 and 0.699863 in 2009.

Besides obtaining the DEA efficiency scores, one can have access to additional analysis with respect to weighting factors, targets for efficiency and benchmarks. The DEA model seeks the best efficiency ratios for each DMU analyzed. Thus, if a variable can affect the efficiency, it is assigned the value zero. We sought, then, to understand which variables were not considered in the analysis of performance, namely the problematic variables (weight zero). 
Table 2: Descriptive statistics of efficiency scores

\begin{tabular}{|l|l|l|l|l|}
\hline & \multicolumn{1}{|c|}{$\mathbf{2 0 0 7}$} & \multicolumn{1}{c|}{$\mathbf{2 0 0 8}$} & \multicolumn{1}{c|}{$\mathbf{2 0 0 9}$} & Average \\
\hline GENERAL & 15 & 12 & 12 & \\
\hline \# efficient companies & 0,798360 & 0,750710 & 0,737080 & 0,762050 \\
\hline Mean & 0,247060 & 0,258100 & 0,274230 & 0,229080 \\
\hline Deviation & 0,196290 & 0,250070 & 0,290550 & 0,245640 \\
\hline Minimum & 1,0000 & 1,0000 & 1,0000 & 1,0000 \\
\hline Maximum & 8 & 6 & 6 & \\
\hline WITH GOVERNANCE & 8 & 0,763865 & 0,699863 & 0,770737 \\
\hline \# efficient companies & 0,848482 & 0,298637 & 0,323143 & 0,252685 \\
\hline Mean & 0,238992 & 0,047 & 0,020285 & 0,245635 \\
\hline Deviation & 0,196286 & 0,047231 & 1,000 & 1,000 \\
\hline Minimum & 1,000 & 1,000 & 6 & \\
\hline Maximum & 7 & 6 & 0,764499 & 0,755649 \\
\hline WITHOUT GOVERNANCE & 7 & 0,741015 & 0,216972 \\
\hline \# efficient companies & 0,761434 & 0,231921 & 0,237492 & 0,2100245 \\
\hline Mean & 0,252714 & 0,322572 & 0,302921 & 0,280245 \\
\hline Deviation & 0,215243 & 1,0000 & 1,0000 & 1,0000 \\
\hline Minimum & 1,0000 &
\end{tabular}

Source: Research data

The variables that most frequently demonstrated weight zero in three years were, in inputs, the variable Total Liabilities and, in outputs, the variables Tobin's $\mathrm{Q}$ and ROA. This indicates that companies must seek improvements in these indicators.

The analysis of the targets presents two highlights, related to slacks and efficiency goals. Regarding slacks, the modeling indicates that when all slacks equal zero, assuming an optimal solution, the DMU being evaluated is efficient. Thus the results demonstrated that all companies considered efficient showed slacks equal to zero. The companies considered inefficient have always showed slacks level in some variable, and the Tobin's $\mathrm{Q}$ and ROA variables revealed slacks in all inefficient firms.

Considering the input-oriented model used in this study, the analysis of the targets aims to determine how the inputs should be reduced for the company to become efficient. This analysis must be run for each company individually, because there is no generic standard for comparison, i.e., the analysis depends on the efficiency of the group of companies under study and will vary from 
sample to sample. As an example, the company GerParanap (efficiency/2007: 0.299460 ) aims to, in the year of 2007, reduce the Operating Expenses input by $78 \%$ and the Total Liabilities and Equity variables by $67 \%$ and $85 \%$ respectively. On the other hand, the same company must increase Tobin's Q by $53 \%$ and ROA by $71 \%$ (FIG. 2).

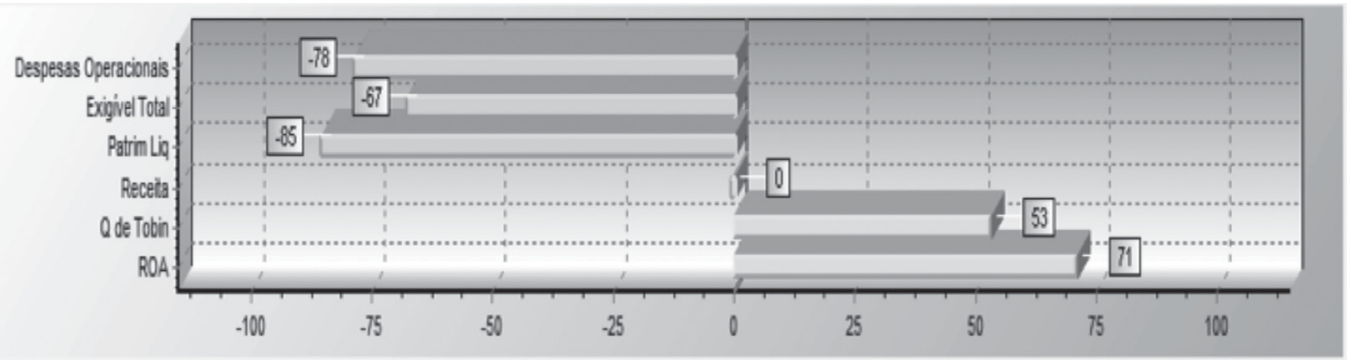

Figure 2: GerParanap's targets for inputs/outputs in 2007 Source: Research data

In turn, TranPaulist (efficiency/2007: 0.669131) aims to reduce the Operating Expenses input by $82 \%$, Total Liabilities by $26 \%$ and Equity by $83 \%$, while raising Tobin's $Q$ by $98 \%$ at the same time (FIG. 3).

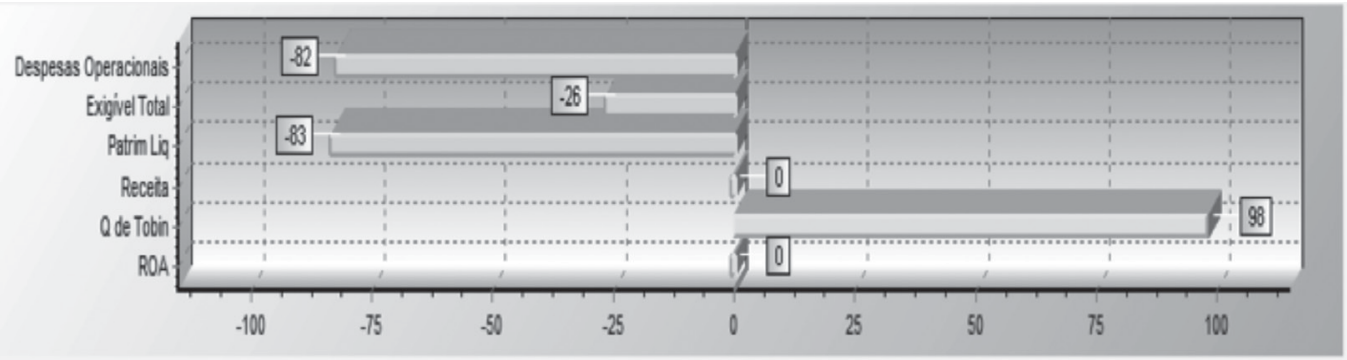

Figure 3: TranPaulist's targets for inputs/outputs in 2007

Source: Research data

Finally, we carried out the analysis of benchmarks or partners of excellence. Through this analysis we verify the partners of excellence of inefficient firms, which mirror the standard of efficiency that should be pursued by these DMUs. Through this analysis it is possible to realize the possibility that outliers do not represent only deviations from the average, but also possible benchmarks to be reviewed by the other DMUs. They may represent the best practices within the subjects studied. Note that the successful firms in each year do not show the need for improvement, i.e., in theory they represent the benchmarks to be 
achieved. The companies considered inefficient require significant changes in their rates to achieve efficiency, as seen in the discussion on the goals.

The survey data showed that companies AESElpa, Afluente and Elektro are the most representative as benchmarks for other companies. Table 3 shows the benchmark companies each year and the number of companies that use them as reference.

Table 3: Benchmark companies and number of references each year

\begin{tabular}{|l|c|c|c|}
\hline \multicolumn{1}{|c|}{ Firms } & $\mathbf{2 0 0 7}$ & $\mathbf{2 0 0 8}$ & $\mathbf{2 0 0 9}$ \\
\hline AESElpa & 10 & 2 & 6 \\
\hline AESTietê & 2 & 3 & 5 \\
\hline Afluente & 12 & 15 & 18 \\
\hline CEB & 7 & 0 & 0 \\
\hline CEEE-GT & 1 & 0 & 0 \\
\hline Celesc & 2 & 2 & 11 \\
\hline Coelba & 0 & 2 & 0 \\
\hline Elektro & 16 & 14 & 16 \\
\hline Eletropaulo & 2 & 4 & 7 \\
\hline TernaPart & 4 & 0 & 0 \\
\hline
\end{tabular}

Source: Research data

In order to illustrate the concept of benchmarks, we will use data from the company CEEE-GT (FIG. 4), which is listed under Level 1 of Corporate Governance and had an efficiency score of $72.14 \%$ in 2008.

In FIG. 4 we show that the companies CEB, Eletrobrás and Eletropaulo, are the benchmarks (references) for company CEEE-GT to achieve efficiency.

After analyzing the efficiency by DEA for the study group, the efficiency scores obtained are regressed against a number of corporate governance and control variables, to identify the existence of possible relationships between governance and efficiency. 


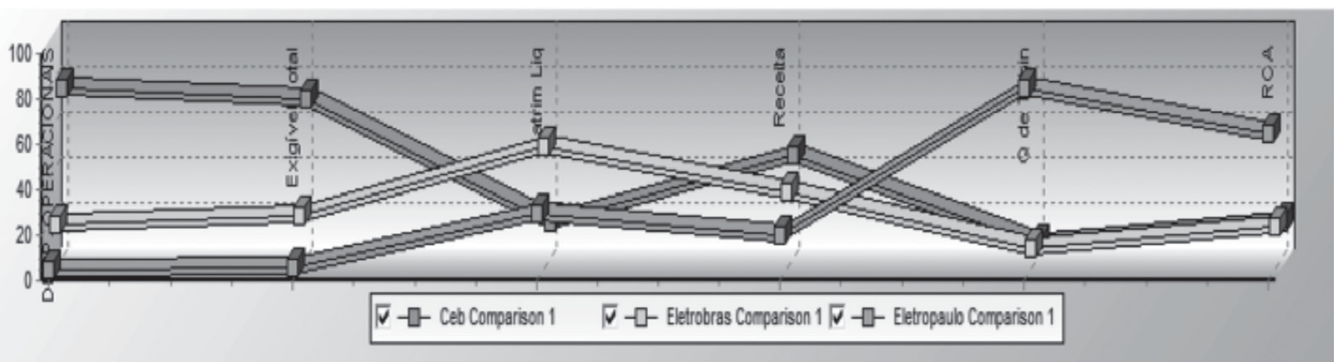

Figure 4: Benchmarks for CEEE-GT in 2008

Source: Research data

\subsection{Regression Analysis}

The econometric model estimated, using Regression Analysis of Panel Data was:

$$
E F_{i, t}=\alpha i+\beta_{1} D C O N T+\beta_{2} D S F C+\beta_{3} S E P+\beta_{4} G I C+\beta_{z} A D H+\beta_{6} S I Z E+\varepsilon_{i, t}
$$

$\mathrm{EF}_{\mathrm{i}, \mathrm{t}}$ represents the efficiency score of firm $\mathrm{i}$ in period $\mathrm{t}$, obtained with the DEA-VRS; and DCONT, DSFC, SEP, GIC, ADH and SIZE are the variables of corporate governance and control explained in Appendix Table A.

According to the literature about corporate governance (CARVALHAL-DA-SILVA; LEAL, 2005; CORREIA, 2008; SHLEIFER; VISHNY, 1997; SILVEIRA, 2004), in the present study, it was expected that the following relations between the efficiency score and the explanatory variables: (a) negative relationship between DCONT and $\mathrm{EF}_{\mathrm{i}, \mathrm{t}}$, indicating that higher concentration of voting rights leads to lower efficiency; (b) positive relationship between $\mathrm{DSFC}$ and $\mathrm{EF}_{\mathrm{i}, \mathrm{t}}$, indicating that higher cash flow concentration leads greater efficiency; (c) negative relationship between $\mathrm{SEP}$ and $\mathrm{EF}_{\mathrm{i}, \mathrm{t}}$, following analogue reasoning about DCONT; (d) positive relationship between $\mathrm{GIC}$ and $\mathrm{EF}_{\mathrm{i}, \mathrm{t}}$, indicating that greater board of directors independence is associated with greater efficiency; and (e) positive relationship between levels of adhesion to governance and greater efficiency.

The Regression Analysis of Panel Data is used when we work with longitudinal data, where a cross section of firms is observed over time. The advantages of using this type of model consist in the possibility of dealing with the heterogeneity of the units and reduce the problems of multicollinearity. There are some methods that allow the dealing with the heterogeneity of data, which 
are: fixed effects and random effects model (STOCK; WATSON, 2004). In order to decide the best model, we carried out the Hausman Test, in Stata/SE 11.0 software, according to Table 4.

The result rejected the null hypothesis (difference in coefficients not systematic). That is, the fixed effects model is most appropriate for this study. Table 5 presents the results of fixed effects model.

The result showed that the variables DSFC and SIZE are statistically significant ( $p$-value lower than 9\%). The DSFC variable presented positive coefficient, as expected, indicating that the higher concentration of cash flow with majority shareholder results in greater efficiency, confirming the initial hypothesis of this study. The result for the control variable "Size" showed that there is negative relationship between efficiency and size, in other words, smaller companies tend to be more efficient according to our data.

The outcome for variables GIC, SEP and ADH are not statistically significant at $10 \%$, and the $\mathrm{ADH}$ variable (adhesion to the governance levels of Bovespa) was the least significant variable in the model ( $p$-value 0.946). The variables not significant GIC and SEP ( $p$-values of 0.177 and 0.152 , respectively) revealed opposite coefficients to what was expected according to the literature of governance.

Table 4: Hausman Test

- qui xtreg escore gic dcont dsfc sep size adh, fe

. estimates store fixed_group

- qui xtreg escore gic dcont dsfc sep size adh, re

. hausman fixed_group

\begin{tabular}{|c|c|c|c|c|}
\hline & $\begin{array}{l}- \text { Coeffi } \\
\text { (b) } \\
\text { fixed_group }\end{array}$ & $\begin{array}{c}\text { ients }- \\
\text { (B) } \\
\text {. }\end{array}$ & $\begin{array}{c}(b-B) \\
\text { Difference }\end{array}$ & $\begin{array}{l}\operatorname{sqrt}\left(\operatorname{diag}\left(V_{-} b-V_{-} B\right.\right. \\
\text { S.E. }\end{array}$ \\
\hline $\begin{array}{r}\text { gic } \\
\text { dsfc } \\
\text { size } \\
\text { adh }\end{array}$ & $\begin{array}{l}-.3267451 \\
.0066677 \\
-.3864607 \\
-.0054218\end{array}$ & $\begin{array}{r}-.162119 \\
.0014957 \\
-.0164511 \\
.0416226\end{array}$ & $\begin{array}{r}-.1646261 \\
.005172 \\
-.3700096 \\
-.0470444\end{array}$ & $\begin{array}{r}.1173964 \\
.0032492 \\
.090535 \\
.0316581\end{array}$ \\
\hline
\end{tabular}

$\mathrm{b}=$ consistent under $\mathrm{Ho}$ and $\mathrm{Ha}$; obtained from xtreg

$B=$ inconsistent under $\mathrm{Ha}$, efficient under Ho; obtained from xtreg

Test: Ho: difference in coefficients not systematic

$$
\begin{array}{rlrl}
\operatorname{chi} 2(4) & = & (b-B) & {\left[\left(V_{-} b-V \_B\right) \wedge\right.} \\
& = & 32.29 \\
\text { Prob }>\text { chi2 } & = & 0.0000
\end{array}
$$

Source: Research data 
Table 5: Results of Fixed Effects Model

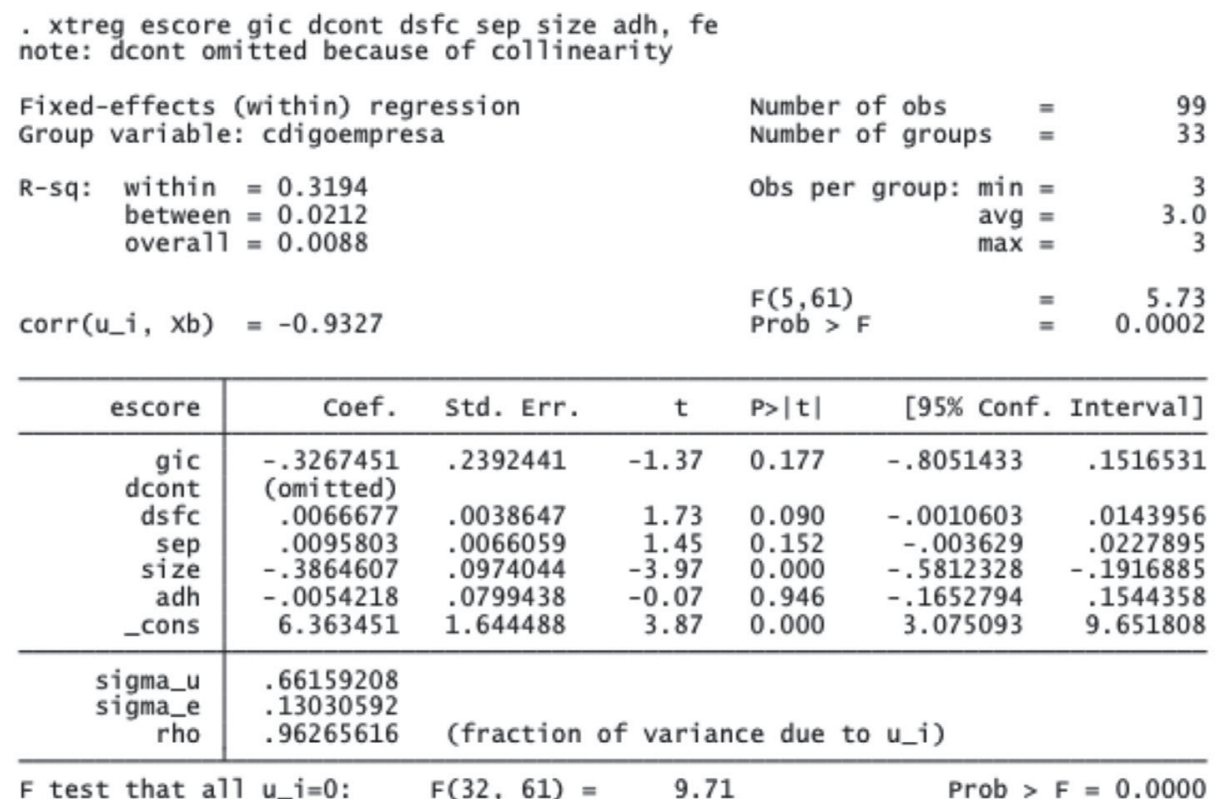

Source: Research data

It appears that, for the sample and period analyzed, the greater was the right over cash flow, greater will be the efficiency measured by DEA, indicating that when the largest shareholder owns higher property on the cash flow, he loses the motivation to use the private benefits of control, minimizing the expropriation of the rights of minority shareholders, as explained by Claessens et al. (2002), Doidge et al. (2005), and Carvalhal-da-Silva and Leal (2005).

For example, in his investigation about the ownership structure of 4,000 companies from 31 countries in Asia, Europe and Latin America, Doidge et al. (2005) observed that if the controlling shareholder holds a reasonable share of preferred shares without voting rights, willing to extract the benefits of control, it reduces the value of the firm in the market, and will also reduce its own capital. Thus, these studies suggest that a higher concentration of cash flow leads to increase in value of the firm. In the present study, we can infer that this concentration increases the efficiency of the organization, as measured by DEA. 


\section{Final Remarks}

As previously seen, the purpose of this investigation was to evaluate whether the governance mechanisms in Brazilian companies in the electricity sector may be positively associated with their efficiency in the period from 2007 to 2009. The study involved two stages: first, we used the DEA-VRS Model to calculate the efficiency score and second, we used regression analysis of panel data to examine a possible relationship between the results from DEA and the governance variables suggested by Carvalhal-da-Silva (2005), Silveira (2004), among others.

By applying the DEA method, we found that the average of efficiency levels of the sample decreased over the years. In 2007, the average efficiency score of companies was 0.79836 , decreasing to 0.73708 in 2009. In 2007, the average efficiency of firms with governance (0.848482) was higher compared to the total sample (0.798360). In 2008, the same happened in this comparison. In 2009, however, the average efficiency of firms with governance (0.699863) was lower compared to the total sample (0.737080).

In the analysis of targets and slacks, the variables that showed the biggest need for improvement in the sample and in the period studied are: in the inputs, Total Liabilities and in the outputs, Tobin's $\mathrm{Q}$ and ROA. It was also found that Tobin's $\mathrm{Q}$ and $\mathrm{ROA}$ revealed slacks in all inefficient firms. Looking at the goals in the input-oriented model used in this study we observe, for example, that the company GerParanap, in 2007, showed efficiency score of 0.299460 , and needs to reduce its operational expenditure by $78 \%$ and decrease inputs Liabilities and Equity by 67 and $85 \%$, respectively. Regarding the analysis of the partners of excellence or benchmarks, the companies AESElpa, Afluente and Elektro are the most representative as references for other companies.

In addition to the DEA model, the study involved a regression analysis of panel data. The Hausman Test showed that the fixed effects model is better for this study. We find that cash flow concentration is positively related to the firm's efficiency, corroborating studies as Claessens et al. (2002), Doidge et al. (2005) and Carvalhal-da-Silva and Leal (2005). These studies indicate that a greater cash flow concentration increases the value of the firm. In the present work, we can infer that such concentration increases the efficiency of the firms, as measured by DEA. Regarding the control variables, the variable "Size" proved negatively associated with efficiency, indicating that smaller firms are more efficient for our sample. 
For future research, we suggest the adoption of different variables for inputs and outputs, such as services expenses, staff costs and number of consumers served by the companies. It would be also interesting to use additional variables to represent the corporate governance mechanisms as, for example, a proxy for disclosure. Another research path would be to address various industry sectors and/or draw comparisons between the same sector in different countries.

\section{Governança Corporativa e Eficiência no Setor Elétrico Utilizando Data Envelopment Analysis: um estudo no mercado de capitais brasileiro}

\section{Resumo}

Diferentes mecanismos de governança corporativa (GC) têm sido sugeridos para minimizar os problemas de agência entre gestores e acionistas, e entre acionistas majoritários e minoritários. O objetivo deste estudo é analisar se os mecanismos de governança corporativa resultam em maior eficiência nas empresas brasileiras de capital aberto do setor elétrico, no período de 2007 a 2009. A hipótese a ser verificada é que quanto menor for a concentração de controle e a dependência do conselho, $e$ quanto maior for a concentração de fluxo de caixa, maior será a eficiência da empresa. A amostra analisada envolveu 33 empresas, 14 são classificadas em um dos níveis de GC (Nível 1, Nível 2 ou Novo Mercado) e as restantes são pertencentes ao mercado tradicional. Para medir a eficiência das empresas, o método não paramétrico DEA (Data Envelopment Analysis) foi usado, e para relacionar a eficiência com as variáveis de governança adotou-se análise de regressão de dados em painel. Os resultados demonstraram que o uso de mecanismos de GC influencia positivamente a eficiência empresarial, mas não na magnitude esperada. Constatou-se que a concentração de fluxo de caixa é associada positivamente com a eficiência das empresas, corroborando a literatura sobre governança. Para trabalhos futuros sugere-se o uso de outras variáveis de insumos e produtos.

Palavra-chave: Governança Corporativa. Eficiência e Data Envelopment Analysis (DEA). 


\section{References}

AGUIAR, A. B.; CORRAR, L. J.; BARISTELLA, F. D. Adoção de práticas de governança corporativa e o comportamento das ações na Bovespa: evidências empíricas. Revista de Administração da USP (RAUSP), v. 39, n. 4, p. 338-347, 2004.

ALVES, D.; RIBEIRO, K.; MANTESE, F. Governança Corporativa e desempenho das ações de empresas do setor elétrico. In: X Seminários em Administração da FEA/USP (SEMEAD), São Paulo. 2007.

ANDRADE, A.; ROSSETTI, J. P. Governança corporativa: fundamentos, desenvolvimento e tendências. 2 .ed. São Paulo: Atlas, 2006.

BANKER, R.; CHARNES A.; COOPER W. Models for Estimation of Technical and Scale

BERLE, A. A.; MEANS, G. C.The modern corporation and private property. New York: MacMillan, 1932.

BOHREN, O.; ODEGAARD, B. A. Governance and performance revisited. ECGI - Finance Working Paper n. 28/2003, 2004. Available at: http://ssrn.com/ abstract $=423461$. Accessed in 03 feb. 2011.

BOVESPA. Novo mercado. Available at: http://www.bovespa.com.br. Accessed in 10 jan. 2011.

BOZEC, R.; DIA, M. Board structure and firm technical efficiency: Evidence from Canadian state-owned enterprises. European Journal of Operational Research, v. 177, p. $1734-1750,2007$.

CADBURY REPORT. London Stock Exchange. 1992. Available at: http://www. ecgi.org/codes/code.php?code_id=132. Accessed in 11 feb. 2011.

CARVALHAL-DA-SILVA, A. L.; LEAL, R. P. C. Corporate Governance Index, firm valuation and performance in Brazil. Revista Brasileira de Finanças, v. 3, n. 1, p. 01-18, 2005.

CARVAlHO, A. G. Efeitos da Migração para os Níveis de Governança da Bovespa. São Paulo: Bovespa Abril/2003. Available at: http://www. novomercadobovespa.com.br. Accessed in 10 Jan. 2011. 
CHARNES, A.; COOPER, W.W.; RHODES, E. Measuring the efficiency of decision making units. European Journal of Operational Research, v. 2, p. 429-444, 1978.

CHIANG, M.; LIN, J. The Relationship between Corporate Governance and Firm Productivity: evidence from Taiwan's manufacturing firms. Corporate Governance, v. 15. n. 5, p. 768-779, 2007.

CLAESSENS, S.; DJANKOV, S.; FAN, J. P. H.; LANG, L. H. P. Disentangling the Incentive and Entrenchment Effects of Large Shareholdings. The Journal of Finance, v. 57, n. 6, p. 2741-2771, 2002.

COASE, R. The nature of the firm. Economica, v. 4, p. 386-405, 1937.

COMISSÃO DE VALORES MOBILIÁRIOS. Recomendações da CVM sobre Governança Corporativa. Rio de Janeiro: CVM, 2002.

COOK, W.D.; ZHU, J. Data Envelopment Analysis: modeling operacional processes and measuring productivity. Kluwer: Academic Publishers, 2003.

COOPER, W. W.; SEIFORD, L. M.; TONE, K. Introduction to Data Envelopment Analysis and Its Uses: with DEA-Solver Software and References. New York: Springer, 2007.

CORREIA, L. F. Um Índice de Governança para Empresas no Brasil. 2008. 274 f. Tese (Doutorado em Administração) - Centro de Pós-Graduação e Pesquisa em Administração, Faculdade de Ciências Econômicas, Universidade Federal de Minas Gerais (CEPEAD-FACE-UFMG), Belo Horizonte, 2008.

CREMERS, M.; FERRELL, A. Thirty years of corporate governance: firms valuations \& stock returns. CELS 2009 4th Annual Conference on Empirical Legal Studies Paper. Yale International Center for Finance Working Paper, n. 09-09. 2010. Available at: http://ssrn.com/abstract=1413133. Accessed in 7 jan. 2011.

DELMAS, M.; TOKAT, Y. Deregulation, Governance Structures, and Efficiency: the U.S. electric utility sector. Strategic Management Journal, v. 26, p. 441-460, 2005.

DESTEFANIS, S.; SENA, V. Patterns of Corporate Governance and Technical Efficiency in Italian Manufacturing. Managerial and Decision Economics, v. 28, p. 27-40, 2007. 
DOIDGE, C.; KAROLYI, G. A.; STULZ, R. M.; LINS, K. V.; MILLER, D. P. Private benefits of control, ownership, and the cross-listing decision. ECGI - Finance Working Paper, n. 77, Dice Center Working Paper n. 2.2005 Available in: http:// ssrn.com/abstract $=668424$. Acessed in: 7 jun. 2011.

FARRELL, M. J. The Measurement of Productive Efficiency. Journal of the Royal Statistical Society, v. 120, n. 3, p. 253-290, 1957.

FEROZ, E. H.; GOEL, S.; RAAB, R. L. Performance measurement for accountability in corporate governance: A data envelopment analysis approach. Review of Accounting and Finance, v. 7, n. 2, p. 121-130, 2008.

GOMES, G. C. A Relação entre a participação nos Níveis Diferenciados de Governança Corporativa da Bovespa e o VAR Patrimonial. 2009. 74 f. Dissertação (Mestrado Profissionalizante em Ciências Contábeis) - Fundação Instituto Capixaba de Pesquisas em Contabilidade, Economia e Finanças (FUCAPE), Vitória, 2009.

GOMPERS, P. A.; ISHII, J. L.; METRICK, A. Corporate Governance and Equity Prices. Quarterly Journal of Economics, v. 118, n. 1, p. 107-155, 2003.

HARDWICK, P., ADAMS, M., ZOU, H. Corporate Governance and Cost Efficiency in the United Kingdom Life Insurance Industry. European Business Management Scholl. Working Paper. United Kingdom, 2003.

HERMALIN, B. E.; WEISBACH, M. S. Board of directors as an endogenously determined institution: a survey of the economic literature. Federal Reserve Bank of New York Economic Policy Review, New York, 2003.

HUANG, L.; HSIAO, T.; LAI, G. C. Does Corporate Governance and Ownership Structure influence performance? Evidence from Taiwan Life Insurance Companies. Journal of Insurance Issues, v. 30, n. 2, p. 123-151, 2007.

Inefficiencies in Data Envelopment Analysis. Management Science, v. 30, n. 9, p. 1078-1092, Set./1984.

JENSEN, M. C. The modern industrial revolution, exit, and the failure of internal control systems. Journal of Finance, v. 48, n. 3, p. 831-880, 1993.

JENSEN, M. C.; MECKLING, W. Theory of the firm: managerial behavior, agency costs and capital structure. Journal of Financial Economics, v. 3, n. 4, p. 305360, 1976. 
KLAPPER, L. F; LOVE, I. Corporate Governance, Investor Protection and Performance in Emerging Markets. World Bank Policy Research Working Paper n. 2818. 2002. Available at: http://ssrn.com/abstract $=303979$. Accessed in 05 feb. 2011.

\section{LAMEIRA, V. J. Governança corporativa, risco e desempenho das}

companhias abertas brasileiras: uma análise do relacionamento entre as práticas de governança corporativa, o risco e o desempenho das companhias abertas brasileiras. 2007. 197 f. Tese (Doutorado em Administração) - Programa de PósGraduação em Administração de Empresas, Pontifícia Universidade Católica do Rio de Janeiro (PUC-Rio), Rio de Janeiro, 2007.

LAMEIRA, V. J.; NESS JR, W.L.; DA MOTTA, L.F.J. Governança corporativa: existe evidências empíricas de impactos no $\beta$ e D- $\beta$. In: V Encontro Brasileiro de Finanças, Sociedade Brasileira de Finanças, 2005.

LAMEIRA, V. J.; NESS JR, W.L.; SOARES, T.D. Governança corporativa: impactos no valor das companhias abertas brasileiras. In: V Encontro Brasileiro de Finanças, Sociedade Brasileira de Finanças, 2005.

LEHMANN, E.; WARNING, S.; WEIGAND, J. Governance Structures, Multidimensional Efficiency and Firm Profitability. Journal of Management and Governance, v. 8, p. 279-304, 2004.

LINS, M. P. E.; MEZA, L. A. Análise envoltória de dados e perspectivas de integração no ambiente do apoio à decisão. Rio de Janeiro: Coppe/ UFRJ, 2000.

LOVELL, K. C. A. Production Frontiers and Productive Efficiency. In: Harold O. Fried, C. A. Knox Lovell and Shelton S. Schmidt. The Measurement of Productive Efficiency. Oxford University Press, Oxford. p. 3-77, 1993.

MACEDO, M. A. S.; CORRAR, L. J. Análise comparativa do desempenho contábil-financeiro de empresas com boas práticas de governança corporativa no Brasil. In: XXXIII Encontro da Associação Nacional de PósGraduação e Pesquisa em Administração (ENANPAD), São Paulo, 2009.

MACEDO, M. A. S.; SIQUEIRA, B. S. Estudo da governança corporativa no Brasil através de uma análise comparativa do IGC e do IBOVESPA no período de 2002 a 2005. In: VI Congresso de Controladoria e Contabilidade. São Paulo: FEA/USP, 2006. 
MELLO, J. S. F. O impacto da governança corporativa no valor de mercado das companhias de capital aberto no Brasil: uma reaplicação. 2007. 108 f. Dissertação (Mestrado em Administração) - Centro de Pós-Graduação e Pesquisa em Administração, Faculdade de Ciências Econômicas, Universidade Federal de Minas Gerais (CEPEAD-FACE-UFMG), Belo Horizonte, 2007.

MENEZES, R. M. de. A estrutura de propriedade e a governança corporativa têm relação com o valor e desempenho das empresas no novo cenário de mercado de capitais brasileiro? 2009. 106 f. Dissertação (Mestrado em Administração) - Fundação Instituto Capixaba de Pesquisas em Contabilidade, Economia e Finanças (FUCAPE), Vitória, 2009.

OKIMURA, R. T. Estrutura de Propriedade, Governança, Valor e Desempenho das Empresas no Brasil. 2003. 132 f. Dissertação (Mestrado em Administração de Empresas) - Faculdade de Economia, Administração e Contabilidade da Universidade de São Paulo (FEA-USP), São Paulo, 2003.

RABELO, S. S. T.; ROGERS, P.; RIBEIRO, K. C. S. Análise Comparativa de Carteiras com Práticas de Governança Corporativa Inferiores e Superiores. In: X Seminários em Administração da FEA-USP (SEMEAD), São Paulo. 2007.

RIBEIRO, M. C. V. Governança Corporativa: um estudo do impacto de seus mecanismos internos sobre o desempenho financeiro e o valor de mercado de bancos brasileiros. 2009. 189 f. Dissertação (Mestrado em Administração) Centro de Pós-Graduação e Pesquisa em Administração, Faculdade de Ciências Econômicas, Universidade Federal de Minas Gerais (CEPEAD-FACE-UFMG), Belo Horizonte, 2009.

ROGERS, P. Governança corporativa, mercado de capitais e crescimento econômico no Brasil. Dissertação (Mestrado em Administração) - Faculdade de Gestão e Negócios, Universidade Federal de Uberlândia, Uberlândia, 2006.

ROSSONI, L. Governança corporativa, legitimidade e desempenho das organizações listadas na Bovespa. 2009. 207 f. Tese (Doutorado em Administração) - Universidade Federal do Paraná (UFPR), Curitiba, 2009.

SHLEIFER, A.; VISHNY, R. W.A Survey of Corporate Governance. The Journal of Finance, v. 52, n. 2, p. 737-783, 1997. 
SILVEIRA, A. D. M. Governança Corporativa e Estrutura de Propriedade: determinantes e relação com o desempenho das empresas no Brasil. 2004. 250 f. Tese (Doutorado em Administração) - Faculdade de Economia, Administração e Contabilidade da Universidade de São Paulo (FEA-USP), São Paulo, 2004.

SILVEIRA, A. D. M.; BARROS, L. A. B. C.; FAMÁ, R. A Qualidade da Governança Corporativa Influencia o Valor das Companhias Abertas no Brasil? In: XXIX Encontro Nacional de Pós-Graduação e Pesquisa em Administração (ENANPAD), Brasília, 2005.

STOCK, J. H.; WATSON, M. W. Econometria. São Paulo: Pearson Addison Wesley, 2004.

\section{VELASQUEZ, M. D. P. A influência da Governança Corporativa no} Desempenho e na Estrutura de Capital das empresas listadas no N1, N2 e Novo Mercado da Bovespa. 2008. 195 f. Dissertação (Mestrado em Administração) - Universidade Federal de Santa Maria (UFSM), Santa Maria, 2008.

VILELA, D. L.; NAGANO, M. S.; MERLO, E. M. Aplicação da Análise Envoltória de Dados em Cooperativas de Crédito Rural. Revista de Administração Contemporânea (RAC), v. 2,p. 99-120, 2007.

WILLIAMSON, O. E. The economic institutions of capitalism. New York: The Free Press, 1985.

ZHEKA, V. Corporate Governance, Ownership Structure and Corporate Efficiency: The Case of Ukraine. Managerial and Decision Economics. v. 26, p. 451-460, 2005. 


\section{Appendix}

Table A - Description of Variables

\begin{tabular}{|l|l|}
\hline \multicolumn{2}{|c|}{ Input Variables } \\
\hline Operating \\
Expenses & $\begin{array}{l}\text { Operating expenses are those not related to the manufacturing environment } \\
\text { (operating costs), but necessary for the company's activity and the main- } \\
\text { tenance of the production source. Selling and administrative expenses are } \\
\text { examples. In the context of studies of efficiency and corporate governance, } \\
\text { Delmas and Tokat (2005), Bozec and Dia (2007) and Feroz, Goel and Raab } \\
\text { (2008) are examples of studies that use this or similar variables. }\end{array}$ \\
\hline Total Liabilities & $\begin{array}{l}\text { Includes all the company's debts to third parties in the short and long term. } \\
\text { Studies using this or similar variables are: Feroz, Goel and Raab (2008) and } \\
\text { Macedo and Corrar (2009). }\end{array}$ \\
\hline Equity & $\begin{array}{l}\text { Includes resources belonging to the owners of the company, involving social } \\
\text { capital, reserves and profits / losses accounts of the year. An example of the } \\
\text { authors who use this variable in their work on governance and efficiency are } \\
\text { Huang, Lai and Hsiao (2007). }\end{array}$ \\
\hline $\begin{array}{l}\text { Net Revenue } \\
\text { (or Operating } \\
\text { Income) }\end{array}$ & $\begin{array}{l}\text { Referred to as net sales revenue the gross revenue minus sales returns, trade } \\
\text { discounts and taxes on sales. Studies that use this or similar variables are } \\
\text { Zheka (2005), Delmas and Tokat (2005), Bozec and Dia (2007), Chiang and } \\
\text { Lin (2007) and Feroz, Goel and Raab (2008). }\end{array}$ \\
\hline Return on & $\begin{array}{l}\text { Return on Assets (ROA) is an accounting performance measure that assesses } \\
\text { a company's current capacity to generate profits for the investor with the use } \\
\text { of its assets, defined as Operating Income divided by Total Assets. Among } \\
\text { the authors who adopt the ROA in works on governance are: Bohren and } \\
\text { Odegaard (2004), Mello (2007), Velasquez (2008), Cremers and Ferrell } \\
\text { (2010), Klapper and Love (2002), Lehmann, Warning and Weigand (2004) } \\
\text { and Carvalhal-da-Silva and Leal (2005). }\end{array}$ \\
\hline Assets (ROA)
\end{tabular}




\begin{tabular}{|c|c|}
\hline То & $\begin{array}{l}\text { Tobin's Q is the market value of shares or equity of the company, plus the } \\
\text { book value of debt divided by total assets, i.e.: } \\
\qquad Q \text { de Tobin }=\frac{\text { (VMAO+VMAP+DIVT) }}{\text { (Ativo Total) }} \\
\text { Where: } \\
\text { VMAO = Market value of common shares (Valor de mercado das ações } \\
\text { ordinárias); } \\
\text { VMAP = Market value of preferred shares (Valor de mercado das ações } \\
\text { preferenciais); } \\
\text { DIVT = Book value of debt or debt capital (Valor contábil das dividas ou } \\
\text { capital de terceiros); } \\
\text { Ativo Total = Total Assets. } \\
\text { Studies using this variable in the analysis of governance are: Okimura (2003), } \\
\text { Silveira (2004); Bohren and Odegaard (2004), Lameira, Ness Jr and Soares } \\
\text { (2005); Silveira, Barros and Famá (2005), Mello (2007), Correia (2008), Ros- } \\
\text { soni (2009), Cremers and Ferrell (2010), Klapper and Love (2002), Gompers, } \\
\text { Ishii and Metrick (2003) e Carvalhal-da-Silva and Leal (2005). }\end{array}$ \\
\hline \multicolumn{2}{|r|}{ Governance Variables } \\
\hline Rights & $\begin{array}{l}\text { Referred to as the control rights of the largest shareholder, i.e. the percentage } \\
\text { of shares in its domain. Studies using this variable are: Silveira (2004), Bohren } \\
\text { and Odegaard (2004), Silveira, Barros and Famá (2005), Lameira (2007) } \\
\text { and Ribeiro (2009). }\end{array}$ \\
\hline $\begin{array}{l}\text { Rights over } \\
\text { the cash flow } \\
\text { (Direito sobre } \\
\text { o fluxo de } \\
\text { caixa - DSFC) }\end{array}$ & $\begin{array}{l}\text { Referred to as the rights over the cash flow, i.e. the property rights of the } \\
\text { majority shareholder (the percentage of common and preferred shares held } \\
\text { by the majority shareholder). Studies using this variable are: Silveira (2004), } \\
\text { Lameira (2007) and Menezes (2009). }\end{array}$ \\
\hline $\begin{array}{l}\text { Separation } \\
\text { between } \\
\text { DCONT } \\
\text { and DSFC }\end{array}$ & $\begin{array}{l}\text { Referred to as the difference between the percentage of voting stock held by } \\
\text { the controlling shareholder and the percentage of total capital that belongs } \\
\text { to him. Studies using this variable are: Silveira (2004) and Correia (2008). }\end{array}$ \\
\hline $\begin{array}{l}\text { Degree of } \\
\text { Independence } \\
\text { of the Board } \\
\text { (GIC) }\end{array}$ & $\begin{array}{l}\text { Referred to as the amount of outside directors divided by total directors. } \\
\text { Works that adopt this variable: Silveira (2004), Velasquez (2008), Correia } \\
\text { (2008) and Ribeiro (2009). }\end{array}$ \\
\hline
\end{tabular}




\begin{tabular}{|l|l|}
\hline \multicolumn{2}{|c|}{ Control Variables } \\
\hline $\begin{array}{l}\text { Adhesion to } \\
\text { Bovespa's } \\
\text { corporate } \\
\text { governance } \\
\text { levels (NDGC) }\end{array}$ & $\begin{array}{l}\text { It consists of a dichotomous variable used to determine whether or not the } \\
\text { company adhered to the levels of governance established by BOVESPA. } \\
\text { If the company has adhered to any of the levels (1, 2 or New Market), the } \\
\text { value 1 is assigned to it, and 0 otherwise. Studies using this variable: Silveira } \\
\text { (2004), Lameira, Ness Jr. and Soares (2005), Silveira, Barros and Famá } \\
\text { (2005), Lameira (2007), Menezes (2009), Rossoni (2009) and Gomes (2009). }\end{array}$ \\
\hline Firm size & $\begin{array}{l}\text { In this study, the size of the company will be represented by the logarithm } \\
\text { of the total assets, as used in the work of Lehmann, Warning and Weigand } \\
\text { (2004), Lameira, Ness Jr. and da Motta (2005), Rossoni (2009), Carvalhal- } \\
\text {-da-Silva and Leal (2005), Correia (2008), among others. }\end{array}$ \\
\hline
\end{tabular}

Source: developed by the authors.

Step 1: Data Envelopment Analysis Model

Inputs

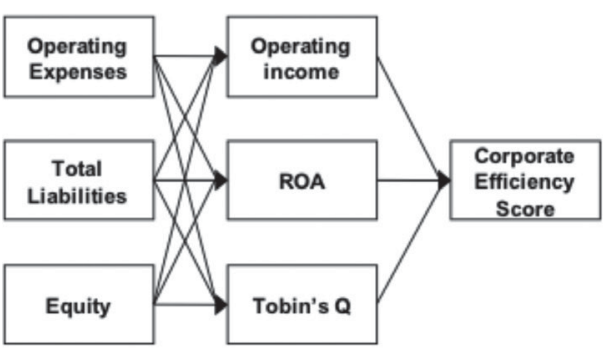

Step 2: Regression Model

\begin{tabular}{|c|}
\hline $\begin{array}{c}\text { Dependant } \\
\text { variable }\end{array}$ \\
\hline $\begin{array}{c}\text { Corporate } \\
\text { Efficiency Score }\end{array}$ \\
\hline
\end{tabular}

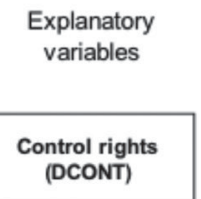

Rights over the cash flow (DSFC)

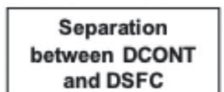
and DSFC

Degree of independance of the board (GIC)

Figure A - Description of study stages

Source: developed by the authors. 